ACTA THERIOLOGICA

Vol. 27, 29: $327-447,1982$

\title{
Grouping Tendencies in Roe Deer under Agrocenosis Conditions ${ }^{1}$
}

\author{
Wojciech BRESIŃSKI
}

\begin{abstract}
Bresiński W., 1982: Grouping tendencies in roe deer under agrocenosis conditions. Acta theriol., 27, 29: 427-447 [With 3 Tables \& 10 Figs.]

Studies were made by means of direct observations and individual marking of the grouping tendencies of roe deer Capreolus capreolus (Linnaeus, 1758) in fields and the factors contributing to this phenomenon. In summer (May-August) roe deer lear alone or family way of life, but in autumn and winter they gather in groups consisting of several to $60-70$ individuals. These groups disperse during the period between the end of April and beginning of May. The average size of groups from September to October was 3.0, from November to March 5.6 and from April-May 3.3 individuals, and depended on the density of these animals. It was also found that the size of the groups is affected by various weather factors, the degree to which the area is wooded, the agrarian structure, degree to which the fields are visited by humans and, in $1969 / 70$, by the depth of the snow cover. The composition of the different groups is not constant, but is subject to fluctuations, mainly depending on the local density of these animals. Groups of roe deer in fields exhibit some degree of internal organization, manifested in the leadership and social hierarchy of different individuals within the groups. It would appear that the grouping of field-living roe deer is caused by stress created in these animals as the result of periodical absence of cover, increase in the frequentation of fields by humans and the effect of weather conditions. While remaining in larger groups the individuals forming them have greater opportunities of fully satisfying their vital needs. It would seem that grouping of roe deer during the autumn-winter period is a manifestation of their adaptation to living in agrocenoses.
\end{abstract}

[Polish Hunting Association, Research Station, 62-055 Czempiń, Poland]

\section{INTRODUCTION}

The occupation by roe deer of agrocenoses was, according to Pielowski $(1970,1977)$ connected with the overcrowding of these animals in forest habitats, with the simultaneous progressive elimination of wooded land and the development of farming based on extremely large fields. A change in the ecological conditions in which the given species lives may bring about significant changes in the character and intensity of occurrence of vital phenomena in these animals including the different organization of population structure (Petrusewicz 1965, 1978). The settlement by roe deer of agrocenoses has caused distinct changes in

${ }_{1}$ Pracę wykonano w ramach problemu MR-II/15 koordynowanego przez Instytut Ekologii PAN.

5- Acta Theriologica 
the way of life of these animals. Under forest conditions roe deer lead a lone or family way of life throughout almost the entire year, keeping together in very small groups (Kurt, 1968; Dzixciolowski, 1979; Fruzinski et al., 1982; and others). In a field habitat, on the other hand, apart from the summer period they are observed to exhibit a tendency to form large groups, sometimes consisting of $60-100$ or more individuals (Schechtel, 1929; Meisnerowski, 1959; Bresiński 1975; Zejda, 1977). The formation of large concentrations is characteristic of animals occupying extensive open spaces, and is a form of the species' adaptation to living under these conditions. The continually progressing changes in the habitat and the scarcity of information on the fauna of agrocenose formed the chief reason for undertaking more detailed studies on the spatial structure of the roe deer in agrocenoses.

The purpose of this study was to ascertain the mechanisms governing the grouping of roe deer in fields and the factors contributing to this phenomenon under the conditions of modern agrocenoses. As fuller knowledge of these problems may contribute to further definition and explanation of the regularities of adaptation processes in roe deer to living under different habitat conditions.

\section{STUDY AREA}

The studies were carried out in the experimental area approx. 15000 ha in extent of the Polish Hunting Association Research Station at Czempin, situated in the western part of Poland. There is little $-6.8 \%$ - wooded land in this area. There are numerous shelterbelts in the form of coverts and windbreaks. The area is intersected by a large number of drainage ditches, a considerable part of which are overgrown by bushes and trees. There are several ponds, often over-grown by reeds or trees, in the natural depression in the area. Deciduous trees line the majority of the roads there, and jointly form shelter of a different kind for game animals, the combined area in 1971 being approx. 239 ha $(1.9 \%$ of the area). About $70 \%$ of the area consists of land cultivated by the large-scale crop system (fields form 5 to approx. 15 ha in extent), while the remainder of the area is occupied by individual farms (size of fields from $2-3 \mathrm{ha}$ ). Agriculture in this area is distinguished by the very great intensity of agrotechnical operations. Further details of the experimental area are to be found in the study by Kaluziński (1982).

Continual observations and studies were carried out on part of the Station experimental area about 2,110 ha in extent, the character of which is similar to that of the whole area.

\section{STUDY METHODS}

The studies were carried out in 6 seasons from autumn to spring from 1969-71 and 1972-1976, and additionally in 1975 they were prolonged over the summer season. During the studies detailed data on the size and composition of the groups of the roe deer were collected. The studies were so arranged that count was made of roe deer over the whole study area within one day, and the total period 
of the studies was 155 days. Observations of roe deer wede made by approaching them on foot, or in a vehicle, or from a raised observation post, using fieldglasses $10 \times 50$ and telescope $40 \times 60$. The number of individuals was recorded for certain groups and their sex and age defined. They were classified in accordance with the following division: single buck, single doe, doe with one; or more. fawns, buck with doe, buck with doe and fawns, does with fawns, single fawns, group of bucks and mixed groupings (cf. Kurt, 1968). In every case data as to the localization of the roe deer and their escape routes were entered on the map: A record was also kept of the current cultivated plant cover of fields, the behaviour of the roe deer and the number of people present in the fields and the places over which they passed. Data on weather conditions and dates at which plants began to grow were obtained from the Plant Breeding and Acclimatization Experimental Station at Borów, situated in the experimental area of the Station. Experimental Station at Borowo, situated in the experimental area of the Station. area of the station by means of collars with numbers; a total of 42 animals being marked between the years 1970-1976 in the area under constant observation. Successive repeated observations of marked individuals made it easier to identify the groups, and supplied data on their composition, variations, home ranges etc. For various reasons (mortality, migrations) only part of these animals (about 20 individuals) were under constant observation, neither did it always prove possible to read the number on marked animals.

Studies on the spatial structure of the population during the summer period were based on observations of marked individuals and identification of certain bucks by means of the description of their antlers and age. From May to OctoberNovember (when the antlers are shed) the places occupied by bucks were recorded on part of the study area of about 510 ha in extent. In all 10 bucks were kept under constant observation, which forms about $40 \%$ of the males recorded in this area. The size of the individual home ranges and of different groups was defined by the methods described by Pielowski (1983).

From 1974-1976 10 does leading groups were shot, and their age defined on the basis of wear of tooth crowns, while conclusions were drawn as to reproduction in a given year from the state of the teats.

\section{SPATIAL ORGANIZATION OF THE POPULATION IN SUMMER}

During the summer period (from mid-May to August) roe deer led a lone or family way of life. At that time the average size of groups fluctuated within limits of $1.3-1.6$ individuals (Fig. 1). Over $60 \%$ of the observations concerned animals living singly, and the value of the dispersion index did not exceed 0.5 , pointing to the non-congregating character of the population's spatial structure (Fig. 2). The relatively high percentage of single does observed (Fig. 3) is most probably due to the biologically conditioned low degree of activity of fawns during the immediate postnatal period. Later on the height of cultivated plants resulted in the young animals being difficult to observe. During this period small groups (3-4 individuals) were sometimes encountered, consisting of bucks and lone does. During the rut (second half of July and first half of August) over $30 \%$ of the observations ( $40 \%$ of the 
population) were of a group composed of a buck and does, and lone young were also encountered (Fig. 1), most probably abandoned by does during chases with bucks.

During the summer period the bucks either led a solitary life or sometimes lived in mixed groups consisting of two bucks or two does and a buck (Fig. 3). Bucks occupied individual coverts on May. On account of the agricultural activities of humans, some parts of the crops which had hitherto provided the bucks with a hiding place disappeared, and the animals were forced to move to neighbouring areas,

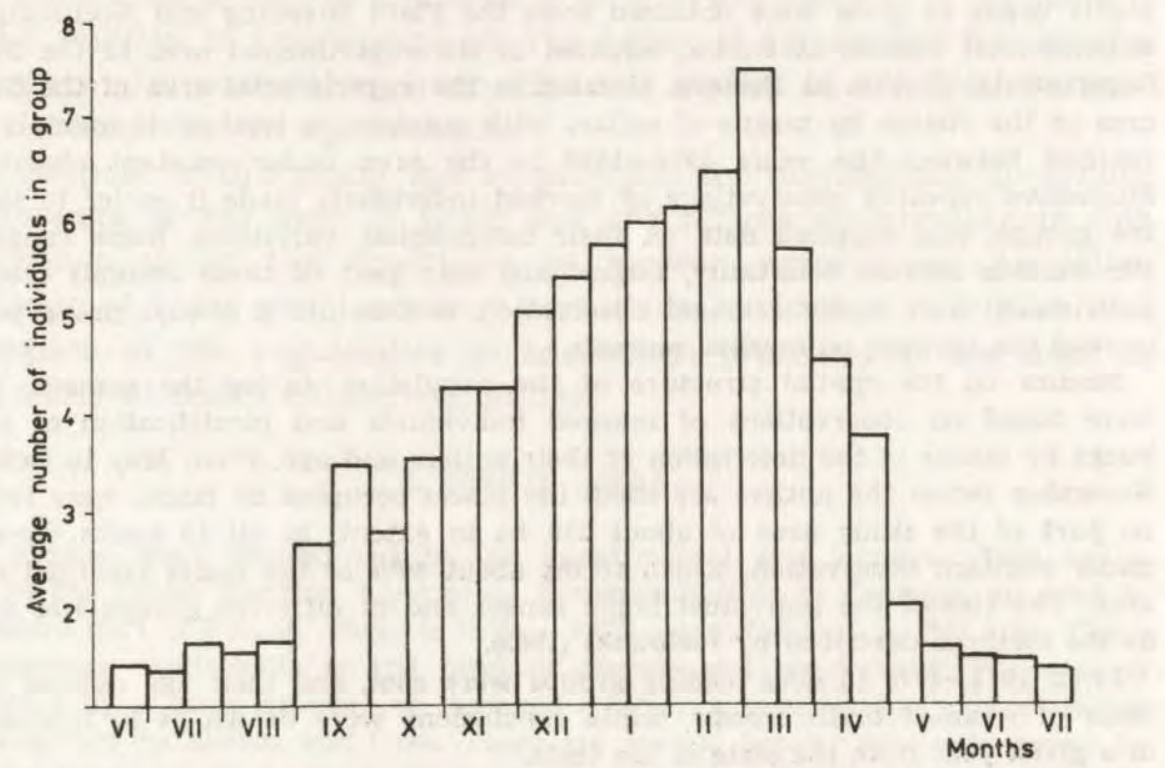

Fig. 1. Average size of groups of field-living roe deer over the yearly cycle (data for period 1969-1971 and 1972-1976).

often already occupied by other males. It may therefore be concluded that the territorial system of bucks, unlike the stability exhibited under forest conditions (Kurt, 1968; Strandgaard, 1972; Ellenberg, 1978, and others) is of a far more dynamic character in fields. Under the study conditions the size of the bucks' home ranges from May to August was on an average about 22 ha, and varied from 12.5 to 50 ha.

\section{AUTUMN-WINTER GROUPING OF ROE DEER}

\section{1. "Compulsory" Grouping}

The first large groups of roe deer were observed at the beginning of September, when they lived chiefly on the very large stretches of stubble. When autumn field work began (harvesting rootcrops and 
maize) the groups of roe deer were observed to increase in size. Animals driven out from the places in which they hitherto lived congregated in areas in which there had been relative peace up to that time. As soon as field work was completed the roe deer dispersed to the places they had previously occupied. During this period the average size of the groups exhibited considerable variation from day to day, and the value of the grouping index oscillated round unity, pointing to the random character of formation of such groups of roe deer (Fig. 2).

\begin{tabular}{|c|c|c|c|c|c|c|c|c|c|c|c|c|}
\hline$d>10$ & & & & & & & & & & & - & \\
\hline$d=1.0$ & & & & & & & & & - & & & \\
\hline $0.5<d<1$ & & & & & & & & & & & & \\
\hline$d<0.5$ & & & & & & & & & & & & \\
\hline & \begin{tabular}{|l|l|}
1 & 2 \\
\end{tabular} & $\begin{array}{ll}112 \\
\end{array}$ & 12 & $\begin{array}{ll}12 \\
\end{array}$ & \begin{tabular}{|l|l|}
1 & 2 \\
\end{tabular} & \begin{tabular}{|l|l|}
1 & 2 \\
\end{tabular} & $\begin{array}{ll}12 \\
\end{array}$ & $\begin{array}{ll}12 & 2 \\
\end{array}$ & $\begin{array}{ll}12 \\
\end{array}$ & 212 & $\begin{array}{lll} & 2 \\
\end{array}$ & 12 \\
\hline Months & \begin{tabular}{|l|} 
VII \\
\end{tabular} & VIII & $1 x$ & $x$ & $\mathrm{XI}$ & XII & 1 & II & III & IV & $1 \mathrm{v}$ & $\mathrm{VI}$ \\
\hline
\end{tabular}

Fig. 2. Distribution of grouping index $d=\frac{(x-\bar{x})^{2}}{\bar{x}(n-1)}$ over the yearly cycle for the study population of field-living roe deer.

1 - up to 15 th of each month, 2-as from 16 th of each month.

\subsection{Winter Grouping}

At the end of October and beginning of November the majority of the roe deer were already living in groups (Fig. 1), but the size of such groups continued to vary. This was due to the lack of shelter, as high cultivated plants had been harvested, while the farmers continued to work in the fields. Groups exhibited greater stability in size after fewer people were present in the fields, where work was interrupted when weather conditions deteriorated (ground frosts, frost, snowfall etc.). During this period (November-March) the value of the grouping index fluctuated above unity, pointing to the grouping character of the population's spatial structure (Fig. 2).

It would seem that the start of formation of groups was at the time of earlier contacts between various roe deer during the period of formation of "compulsory" groups. It may be concluded that the grouping process itself among roe deer is directly connected with shelter conditions and increasing movement of humans over the fields.

\section{SPRING DISPERSAL OF GROUPS}

Groups begin to disperse in early spring, at the end of March beginning of April (Fig. 1), which most often coincided with the time at which plants began to grow. Occasionally, when weather conditions deteriorated during this period (return of winter weather) or there was 
earlier increase in the intensiveness of field work, roe deer were observed to join in groups of a "compulsory" character, as they had in autumn. The final dispersal of winter groups took place at the end of April - beginning of May (Fig. 1), by which time cultivated plants had reached a height of $20-30 \mathrm{~cm}$, providing to roe deer with sufficient cover. At that time (April - first half of May), the value of the concentration index varied round unity, pointing to the random nature of the grouping of roe deer (Fig. 2). Dispersal took place as the result of spontaneous departure from, or reciprocal driving out of different individuals from the group. Bucks were the first to leave the groups (Fig. 3).
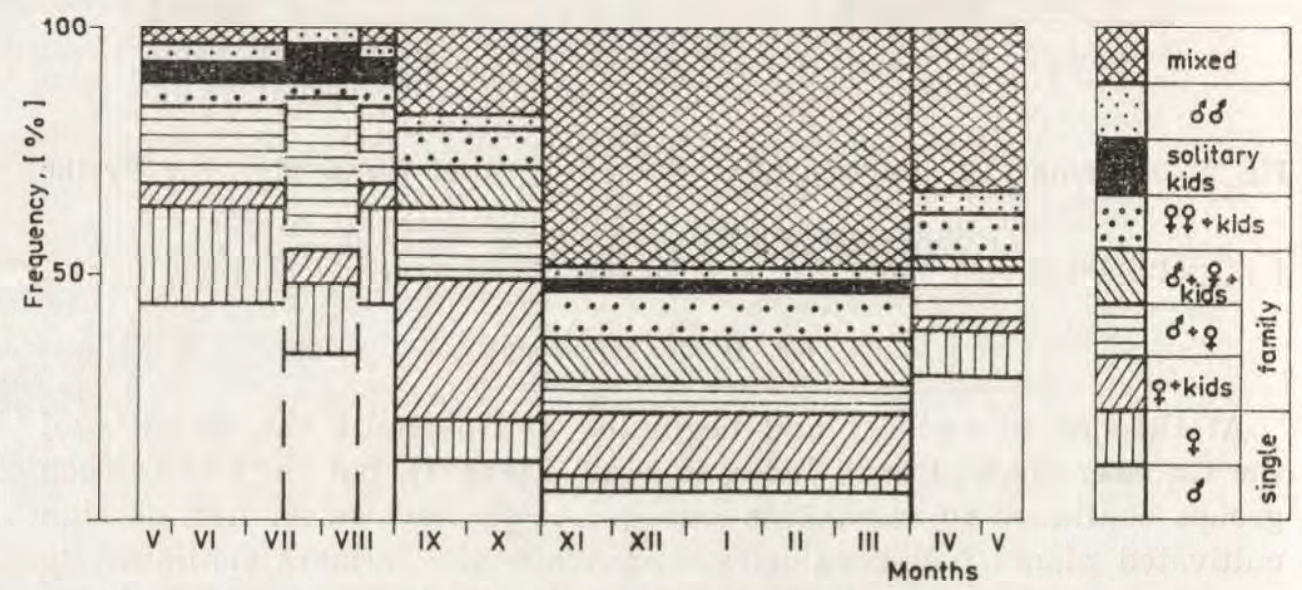

Fig. 3. Average percentage of different types of field-living roe deer groups over the yearly cycle in per cents of observations (data for period 1969-1971 and 1972-1976).

\section{SIZE OF GROUPS}

The average size of groups of roe deer showed a tendency to increase as from September, to reach a maximum in the first half of March (Fig. 1). This was followed by a relatively abrupt drop in the average size up to the beginning of May, when the value characteristic of the summer period was reached. During the study period the average size of "compulsory" groups (September-October) was 3.0, autumn-winter (November-March) 5.6 and during the spring dispersal period 3.3 individuals (Fig. 4). In different years the average size of groups from November to March varied from 3.7 to 7.7 individuals. At this time during the study period an average of almost $50 \%$ lived in groups of from $4-10$ roe deer, while more than $30 \%$ of the study population lived in groups of 11 or more animals (Fig. 4). In different seasons the pro- 
portion of roe deer in groups of 11 or more individuals varied, reaching almost $60 \%$ of the population during the $1969 / 70$ season. The largest group observed in the study area was formed of 44 roe deer (January 1976). Outside the study area groups were sometimes encountered consisting of $60-70$ animals, despite the similarity of habitat conditions.

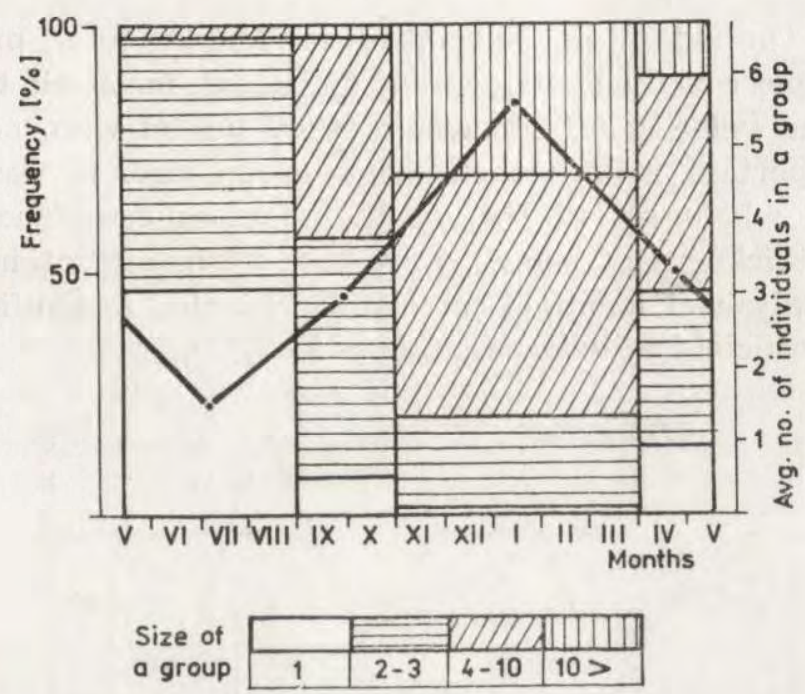

Fig. 4. Average size of groups (continuous line) and percentage of roe deer in groups of different size depending on the season of the year (data for 1969-1971 and 1972-1976) covering observations of 9948 individuals.

\subsection{Size of Groups and Density of Roe Deer}

The density of roe deer was an important factor affecting the mean size of the groups. The greater the density of these animals, the larger

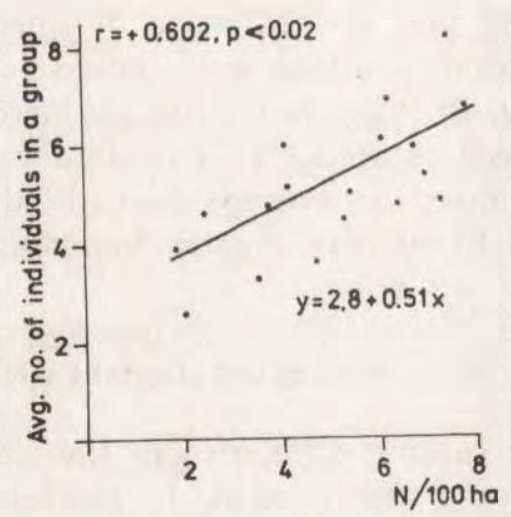

Fig. 5. Relation between size of groups of roe deer and local population density in winter (November-March). 
the groups they formed (Fig. 5). A similar result was obtained when analyzing summarised data for the whole study area in different seasons $(r=+0.780, p<0.1)$.

\subsection{Group Size and Weather Factors}

During the period from November to March total precipitation, duration of snow cover and its average thickness, mean air temperature and mean wind velocity for the whole study period were not found to exert any important influence on mean group size. It was, however, found that a whole set of the weather factors examined, with the exception of thickness of snow cover, had an important influence on group size. Analysis of manifold correlation revealed a significant degree of relation (coefficient of determination $=99.57 \%$ ).

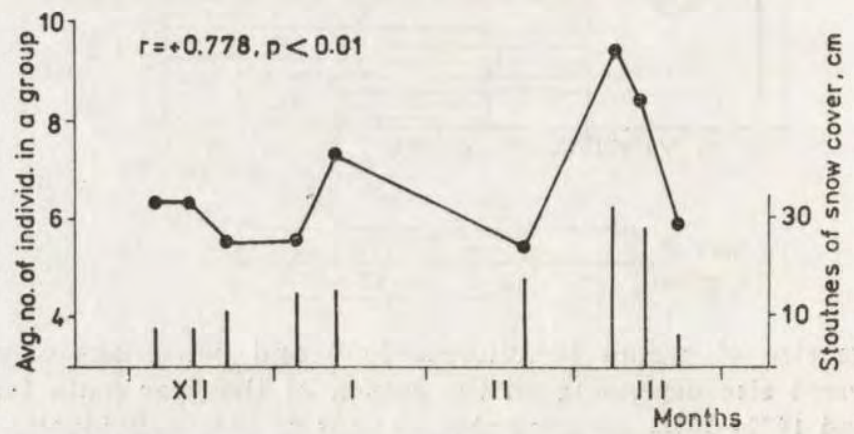

Fig. 6. Relation between size of groups of roe deer (continuous line) and thickness of snow cover (vertical lines) in winter 1969/70.

The weather parameters analyzed were not found to exert any important influence on group size in different study seasons. It was only in winter of 1969 that the influence of thickness of snow cover could be seen. Significant relations were found for this factor during the above period (Fig. 6). Together with an increase in thickness of snow cover the roe deer exhibited an increased tendency to gather in groups. During this winter, the average depth of the snow was approx. $11 \mathrm{~cm}$ (sometimes up to $50 \mathrm{~cm}$ ), greatly impeding access to food for these animals.

\subsection{Size of Groups and Habitat Factors}

An important factor causing difference in the size of groups was the degree to which the area was wooded. In treeless fields groups were larger than those in wooded land (Fig. 7). The agrarian structure of field also affected the grouping of roe deer, It was found that in fields 


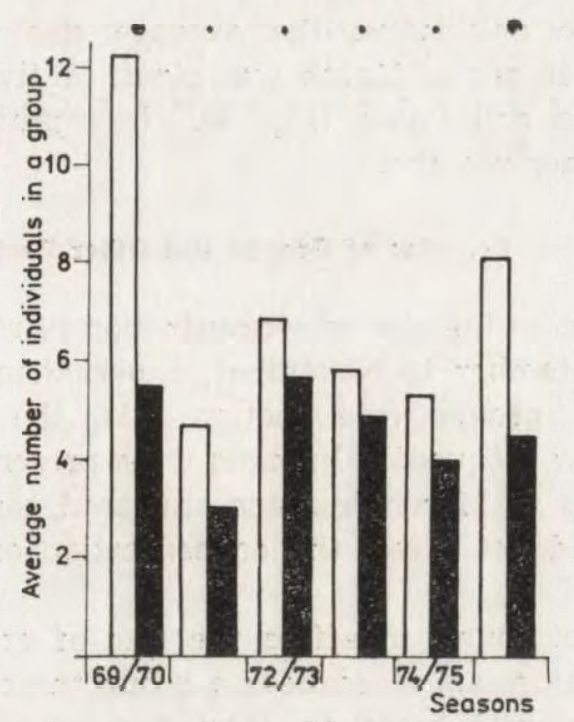

Fig. 7. Average size of groups of roe deer in treeless areas (light columns) and wooded areas (dark columns) from November-March in successive seasons of studies. Significance of differences with levels of $p<0.01$ (large dots) and $p<0.05$ (small dots) indicated above columns.

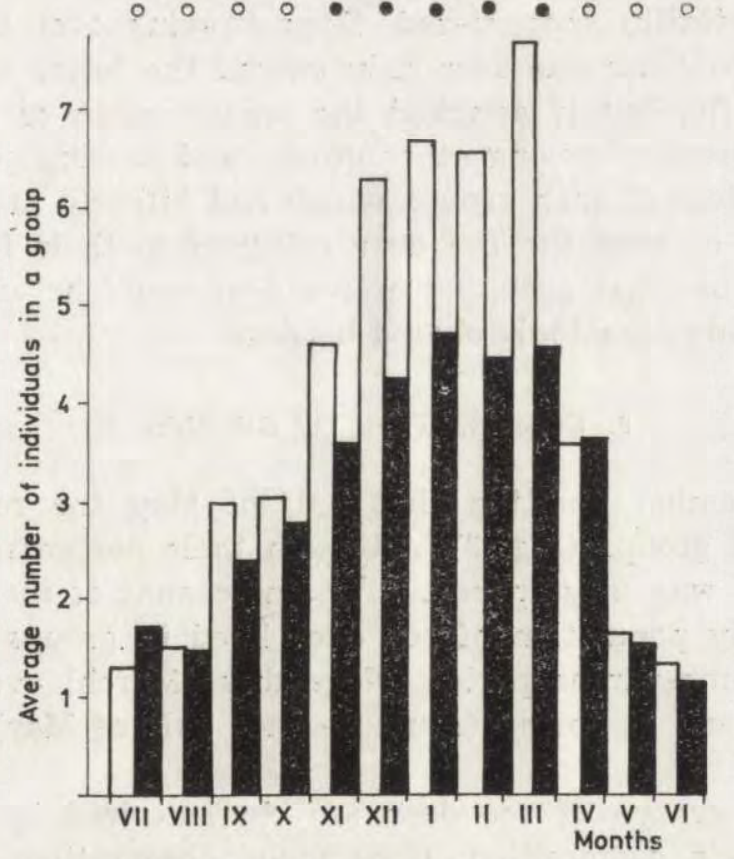

Fig. 8. Average size of groups of roe deer in fields under iarge-scale cultivation (white columns) and small-scale cultivation (black columns) over the yearly cycle (data for 1969-1971 and 1972-1976). Differences occurring were significant with level of $p \leqslant 0.05$ (black circle) and not significant with level of $p>0.05$ (white circle). 
under large-scale cultivation the average size of groups during the period from November to March was significantly greater than in fields under small-scale cultivation (Fig. 8). No significant differences were found for any other months.

\subsection{Size of Groups and Other Factors}

Man's influence on the size of concentration of roe deer was manifested chiefly from September to November, a period in which roe deer lived in "compulsory" groups (see section 5.1), the size of such groups depending on how frequently humans were present in the fields. During a later period up to March humans appeared comparatively seldom in the fields and did not affect the concentration of roe deer $(r=+0.273$, $p>0.1$.

Foxes were not found to affect the size of groups of roe deer, and when these predators appeared near a group the roe deer did not appear to be uneasy. It would, however, seem that the calm behaviour of these herbivores constituted a measure of their safety to the fox. Dogs also were not found to exert any important influence on the size of groups of roe deer. During the period of collecting material for this study dogs were only sporadically encountered. Dogs straying over the fields but not attempting to chase roe deer only caused the latter to watch such predators carefully, but if attacked the whole group of roe deer immediately fled, pressing among other groups and causing general disturbance of the system of such groups which had hitherto prevailed. After a certain length of time the roe deer returned to their former places. It is not impossible that grouping of roe deer could be affected in the event of their being repeatedly chased by dogs.

\section{COMPOSITION OF GROUPS}

Between September and the first half of May the roe deer lived chiefly in mixed groups (Fig. 3). Although their percentage from September-October was only approx. $19 \%$, on account of their size almost $50 \%$ of the study population of roe deer lived in groups of this kind. During the autumn-winter period (November-March) over $80 \%$ lived in such groups, and in spring (April - first half of May) almost $60 \%$ of the roe deer.

The different groups of roe deer are characterized by considerable variations in their composition. Continuous observations of a chosen group showed that there was marked and constant exchange of individuals (Table 1). It would seem that the degree of interchange of individuals in different groups in the given area depends to a great extent 
on the number of roe deer living there. If the value of standard deviation (SD) is taken as a measure of fluctuations in group size, then significant relations are found between changes in composition and population density (Fig. 9). In areas with higher density of roe deer interchange of individuals in different groups was greater.

\section{Table 1}

Changes in the composition of a selected group of roe deer during the $1972 / 73$ season.

\begin{tabular}{|c|c|c|c|c|c|c|c|c|c|}
\hline Datum & $\begin{array}{c}\text { Group } \\
\text { size }\left(\stackrel{+}{+}, \sigma^{*}\right)\end{array}$ & $\begin{array}{c}\stackrel{9}{+} \\
\mathrm{A}-08\end{array}$ & $\begin{array}{c}0^{x} \\
B-02\end{array}$ & $\begin{array}{c}\text { Marke } \\
\sigma^{*} \\
\text { B- } 03\end{array}$ & $\begin{array}{c}1 \text { indiv } \\
\text { } \\
\text { B-04 }\end{array}$ & $\begin{array}{c}\text { duals } \\
\sigma^{*} \\
\text { B-06 }\end{array}$ & $\begin{array}{c}\text { grol } \\
\text { g } \\
\text { B-10 }\end{array}$ & B-20 & $\begin{array}{c}O^{*} \\
B-28\end{array}$ \\
\hline 13.XII.'72 & $9(6,3)$ & - & - & + & + & - & + & - & - \\
\hline & & & & + & + & & + & - & \\
\hline 20.XII. & $9(5,4)$ & - & - & + & + & + & + & - & + \\
\hline 22.XII. & $6(4,2)$ & - & - & + & + & - & - & - & - \\
\hline 29.XII. & $9(6,3)$ & - & - & + & + & - & + & - & - \\
\hline 2.I.73 & $5(3,2)$ & $\overline{-}$ & $\overline{-}$ & + & + & $\overline{-}$ & - & $\overline{-}$ & $\overline{-}$ \\
\hline 23.I. & $14(8,6)$ & + & + & + & + & - & - & + & - \\
\hline 3.II. & $6(4,2)$ & - & - & + & + & - & - & - & - \\
\hline 14.II. & $6(4,2)$ & - & - & + & + & - & - & + & - \\
\hline 19.II. & $10(6,4)$ & + & - & + & + & - & - & + & - \\
\hline 26.II. & 10 (?, ?) & + & - & + & + & - & - & + & - \\
\hline 6.III. & & - & - & + & + & - & - & - & - \\
\hline 19.III. & $7(5$, & + & - & + & + & - & - & + & \\
\hline 22.III. & 11 ?? & & - & + & + & - & - & + & - \\
\hline 4.IV. & $5(3,2)$ & - & - & + & + & - & - & - & - \\
\hline
\end{tabular}

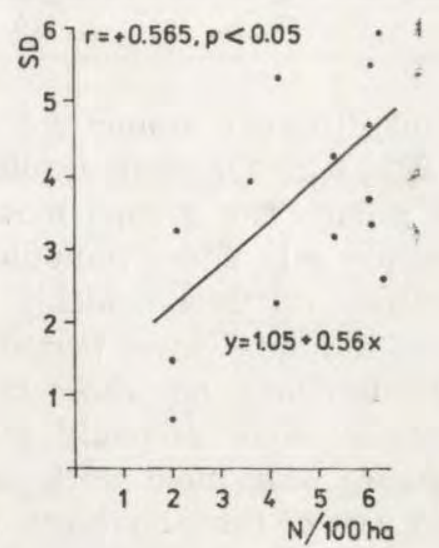

Fig. 9. Changes in size (SD) of chosen groups of roe deer depending on local population density.

It would appear that there are, however, certain constant groups within different congregations - possibly of a family character, forming a kind of core round which the other animals congregate. Evidence of this is supplied by the fact that the same individuals constantly stay 
together in groups (Table 1). In the example presented both individuals - doe B-04 (7-8 years old) and roebuck B-03 (3-4 years old) were caught simultaneously and in the same place, marked, and released. It is possible that the buck B- 03 was the progeny of doe B- 04 .

\section{TERRITORIES OF GROUPS}

Different groups of roe deer lived in a definite area, varying in size from approx. 69 to approx. 225 ha - average approx. 147 ha (Table 2).

Table 2

Size of territory occupied by groups of roe deer which included marked individuals.

\begin{tabular}{|c|c|c|c|c|}
\hline \multicolumn{2}{|c|}{ Group size } & $\underset{\text { observ. }}{\mathrm{N}}$ & $\begin{array}{c}\text { Area } \\
\text { size, ha }\end{array}$ & $\begin{array}{l}\text { Marked } \\
\text { individuals }\end{array}$ \\
\hline 7.9 & $5-14$ & 15 & 169 & 오 B-04 \\
\hline 7.9 & $3-10$ & 8 & 81 & B -04 \\
\hline 5.1 & $2-9$ & 9 & 225 & O B-06 \\
\hline 7.2 & $3-21$ & 11 & 194 & $0^{x}$ B-06 \\
\hline 7.9 & $3-17$ & 8 & 100 & क B-06 \\
\hline 7.7 & $6-9$ & 10 & 125 & 오 $\mathrm{A}-25$ \\
\hline 7.5 & $1-12$ & 10 & 100 & 오 $\mathrm{A}-25$ \\
\hline 4.0 & $3-5$ & 5 & 69 & 오 $\mathrm{A}-10$ \\
\hline 6.6 & $3-21$ & 9 & 200 & 와 $\mathrm{A}-10$ \\
\hline 7.2 & $3-14$ & 10 & 125 & ㅇ $\mathrm{A}-10$ \\
\hline 7.0 & $3-14$ & 14 & 94 & O B-20 \\
\hline 7.4 & $4-14$ & 13 & 150 & ㅇ $\mathrm{A}-28$ \\
\hline 12.1 & $4-20$ & 8 & 206 & 우 A-28 \\
\hline 4.1 & $2-9$ & 17 & 219 & $0^{x}$ B-28 \\
\hline
\end{tabular}

The size of territories of different groups did not depend on the size of the groups $(r=+0.032, p>0.05)$, neither did they defend the area occupied by the given group. The groups moved to the home ranges of other groups in principle only under compulsory conditions and then they endeavoured to return relatively quickly to the place of formed residence. For the whole autumn-winter period the group did not live on the total area of the territory, but chose certain parts of it which, under the given conditions, were probably those most favourable to their existence. For instance when field work was intensified they lived in a comparatively quiet part of their territory. When winds were strong they chose places near natural shelters or depressions in the area. When the thickness of the snow cover made it difficult for them to reach their food they moved to places in which the wind had swept the snow away, or to the vicinity of open clamps with silage etc. When a group was driven away from its territory it returned to it after a certain time.

In general it can be said that the territories occupied by groups of field roe deer exhibit some similarities to the home ranges of the 
hare described by Pielowski (1972). They consist of large areas of movement defined by the limits of escape and smaller, periodically occupied accurately defined areas situated within the former. It is possible that this form of spatial use of an area is typical of animals living in open land.

\section{INTERNAL ORGANIZATION OF GROUPS}

During the period autumn-winter-spring the groups of roe deer exhibited some degree of internal organization, expressed inter alia in leadership and social hierarchy of different individuals within the group.

\subsection{Leadership}

The escape of a group was initiated by an individual which was the first to begin running away. These were most often does, and less frequently fawns and bucks (Fig. 10). It may be concluded that the

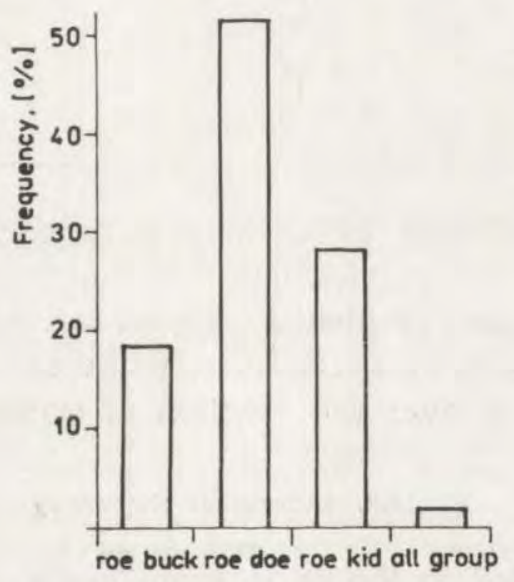

Fig. 10. Proportion of different individuals taking part in initiation of the escape of roe deer groups based on 163 observations.

reaction of fawns is spontaneous in character. Not infrequently they iniciated the group to escape, running near other roe deer and even other species of animals, e.g. hares. While the group was in movement a different individual often passed to the front, taking upon itself the function of leader, and continuing from then onwards to set the direction in which the animals escaped. These were usually does, and most often individuals of middle age ( $3-5$ years old) which had young born that year (Table 3). Often when the group was staying in an "alien" area the bucks initiated the return to the place in which they lived perma- 
nently. In the event of the sudden loss of the individual currently leading the group (e.g. by its being shot) there was only a short moment of confusion and then another individual immediately took the lead, and set the direction for escape. It may therefore be concluded that in each group there is a large number of potential candidates ready to take upon themselves the function of leader, depending on the situation. It is not finally known whether in a large group the function of leader is linked for the whole time with one and the same individual. The observations

Table 3

List of leader does shot during the period 1975-1976. + leading young, ? - no information as to young.

\begin{tabular}{ccc}
\hline Age years & Size of leaded group & Information as to young \\
\hline $3-4$ & 7 & + \\
$3-4$ & 6 & + \\
$3-4$ & 12 & + \\
$4-5$ & 15 & + \\
$4-5$ & 20 & + \\
$4-5$ & 36 & + \\
$4-5$ & 6 & + \\
$5-6$ & 10 & + \\
$6-7$ & 13 & + \\
$8-9$ & 9 & \\
\hline
\end{tabular}

made of marked roe deer living in a large enclosure (approx. 15 ha) suggested that one doe carried out this function. Field observation, in which it was possible to identify given individuals by characteristic features of their external appearance, point to the fact that the same individuals often took over the function of leader in given groups.

\subsection{Individual Hierarchy}

Individuals included in the given group were not all equal in respect of hierarchic relations. This was particularly clear in the relations between bucks during the period the groups were formed. Numerous skirmishes were observed at that time between bucks, as the result of which older individuals certainly higher in the hierarchy tolerated the presence of younger individuals in the group or allowed them to join the group. With the passage of time the bucks became less belligerent and fights between them ceased completely when they had shed their antlers.

During mild winters, when food was plentiful, hierarchic relations were not clearly evident, but during the severe and snowy winter of $1969 / 70$ they were far more distinctly defined. During that time the possibility of obtaining food was greatly reduced and the older bucks 
took priority in feeding at open clamps with silage or in places in which food had been laid out for the animals. These bucks drove off the younger individuals and does, and particularly fawns, which tried to approach the food first.

\section{DISCUSSION}

The concentration of field roe deer during the autumn-winter period is, as Kałuziński (1967) suggests, directly connected with the deteriorating shelter conditions. There is no doubt that a whole set of factors contributes to this phenomenon. In addition to the lack of cover deteriorating weather conditions, increase in human activity in fields and straying dogs also have their effect. It is of course obvious that under such conditions humans and dogs do not always become a direct threat to roe deer, but they are an important scattering factor. It is, however, well known that the animals' reaction to fright is an equally strong stimulus as a state of direct threat (Tinbergen, 1951). As a result roe deer are obliged to maintain constant vigilance and to keep a suitable distance away from these factors. Additionally during that time collective vigilance ensures that the roe deer are able to perceive the danger sufficiently early and consequently to react in a way appropriate to the given situation. Büttner (1980) showed that roe deer living in large groups can devote more time to satisfying their individual living requirements. It would therefore appear that the group way of life gives these animals a feeling of greater security, and at the same time makes it possible for the various individuals to carry out their normal living activities. In spring, when cultivated plants provide sufficient shelter for roe deer, the feeling of danger is greatly reduced. It is probably in consequence of this that the groups disperse and the roe deer begin to lead a lone or family way of life, probably also connected with these animals' preparation for the reproduction period.

Kałuziński (1967) has described the way in which field-living roe deer combine in groups, this process following a specific ritual. This type of phenomenon was not observed during our studies and it would appear that the impetus for formation of such groups is given by the animals forming "compulsory" groups.

In forest habitats roe deer live singly or in small groups of a family character (Kurt, 1968), whereas in small woods in fields (Strandgaard, 1972) and in fields the tendency of these animals for form a group is of a more random character. Groups are formed by congregation of a family and single individuals which most probably lived in the given area. There may also be so-called "alien" individuals - ephemerical roe deer 
undergoing micro-migration or migration, sometimes even from considerable distances (Strandgaard, 1971, 1972; Myrberget, 1973; Pielowski, 1982). The fact itself of the formation by field-living roe deer of groups consisting of 15 or more, or even 100 individuals, distinguished by constant variations in composition, would appear to confirm the supposition that these animals congregate in a purely random way.

Strandgaard (1972), in studying a roe deer population living in a small wood situated in fields, found that there is considerable interchange of individuals among the different groups. A similar situation was observed in numerous species of animals living in open country (Estes \& Estes, 1970; Leuthold, 1970, 1971; Kitchen, 1974; and others). This has also been observed in field-living roe deer, but among species of animals living in woods and forests the composition of the groups is of a far more stable character, e.g. roe deer (Kurt, 1968), or red deer (Dzięgielewski, 1973). Sdobnikov (1935) and Baskin (1970) in describing the way of life of reindeer, found that herds of reindeer as a whole are not nificant relation between interchange of individuals in a group dependis also the case in respect of groups of roe deer living in fields. The constant appearance together of a certain number of individuals in the groups may show that these animals form as it were, the core of the group, round which the remaining individuals congregate, but lead an independent way of life. It may be that this is a typical form of group organisation for animals living in open areas. In places in which their numbers are small groups of field-living roe deer may form a sort of closed whole, into which new individuals are unwillingly admitted (Pielowski, 1970). The studies confirmed this situation and showed the significant relation between interchange of individuals in a group depending on the local density of the population of these animals.

Does, and especially those with young, are usually the leaders of a group (Nečas, 1960; Kałuziński, 1967; Pielowski, 1970). Kałuziński (1967) suggests that the age and experience of a given individual were decisive in its becoming a leader. As we found during the course of our studies these were females chiefly belonging to the medium age classes, which had produced young in the given year. Pielowski (1970) suggests that this is directly connected with the annual sex cycle of the males, evoking given physiological and psychological changes in them. Changes of this type are far less strongly manifested in does and make them most suitable for the function of leadership in the group. The role of leader and subordination to it of the other animals in the group is not so one-sided as in the case of red deer herds (Allee et al., 1958; Dzięgielewski, 1973; and others). The sudden death of a leader caused longlasting confusion in the herd, whereas a phenomenon of this kind is not observed in the 
case of roe deer, with which this function is very quickly taken over by another individual. Sdobnikov (1935) and Baskin (1970) found with reindeer that in addition to the main leader, assistant leaders help it to look after the safety of the herd and direct it. It may therefore be concluded that in addition to the current leader, there are also potential candidates for this function within the groups of roe deer, depending on the situation in which they find themselves. It has not been established beyond doubt whether this function is carried out throughout the whole period by one and the same individual, although numerous observations would seem to confirm this state of affairs. Pielowski (1970) suggests that the take-over of the function of leader is decided by the specific initiative shown by a given watchful and experienced individual, in which the other animals begin to place confidence and submit to in matters of their safety. It may be that these are also roe deer which form the core of the group and posses the best knowledge of the area.

The average sizes of groups of field-living roe deer given by Zejda (1978) for areas in Czechoslovakia greatly differ from those found in the present studies. They are probably due to the different living conditions formed for these animals by the uniform character of largescale fields characteristic of Czechoslovak agriculture, and the mosaic of large and small fields in the Czempin district. The differences observed in group size for small-scale and large-scale cultivated fields confirmed this phenomenon. The fact that large-scale fields are distinguished by greater density of roe deer than small-scale fields certainly influences this situation (Bresiński, 1976). Metelski (1975) found in area varying from wooded land to steppe that the average group size of roe deer increases with decrease in the degree to which the area is wooded. A similar situation was observed among field-living roe deer. The local density of populations of these animals does not influence this phenomenon, as wooded areas are distinguished by larger numbers of these mammals than is the case of open fields (Bresiński \& Chlewski, 1980). It may therefore be concluded that in this case the decisive factor is formed by the different living conditions arising from the greater amount of cover available for roe deer.

Significant differences in the size of groups formed by roe deer were found in many cases of animals of the same species living in different habitats (Nečas, 1960; Leuthold, 1970; Kummer \& Kurt, 1973; Franklin et al., 1975; Peek et al., 1975; Reichholf, 1980; and others). These animals live in decidedly larger groups in open territory. Roe deer in treestands lead a mainly lone or family way of life through the whole year, and the size of the groups they form does not exceed 10 individuals (Kurt, 
1968; Pielowski, 1970; Dzięciołowski, 1979; Fruziński et al., 1983; and others). Groups of roe deer in fields during the autumn-winter period, however, consist of several, or approximately $10-20$ individuals, or even over 100 (Schechtel, 1929; Meisnerowski, 1959; Pielowski, 1970; Bresiński, 1975; Graczyk \& Bereszyński, 1978; Zejda, 1978). The present studies also showed that the decided majority live in mixed groups as compared with animals occupying a forest habitat (Kurt, 1968).

According to Manning (1976) group organization in vertebrates is dynamic in character, varying with a change in conditions. Different living conditions are created for animals of the same species as the result of their living in different habitats. In open areas formation of large groups provides these animals with more favourable conditions for survival, this being a manifestation of their adaptation to living under these conditions (Allee et al., 1958; Walther, 1970; Manning, 1976; and others). In the light of earlier discussion it may be concluded that roe deer respectively in wooded or open land lead a different way of life during the autumn-winter period. In comparison with conditions in wooded land, in fields these animals are subject to constant stress, due to lack of shelter, the need for constant vigilance in order to avoid danger, and deterioration in weather conditions. Under these conditions, by keeping together in large groups, the individual animals make it possible to carry out their normal activities for living, and consequently for survival. In periods of extreme weather conditions, chiefly abundant snowfall making it difficult for roe deer to obtained food, their combined efforts to scrape away the snow cover and search for food, may provide better conditions for survival. It may therefore be concluded that the periodical change in the spatial structure in roe deer populations in agrocenoses is a manifestation of the progressive adaptation of this species to living under the conditions of the contemporary agricultural landscape. At the same time it may form evidence of the depending ecological divergences between the two ecotypes. The permanent occupation of agricultural land by the roe deer is an example of its great plasticity and the adaptability of this species to living under different conditions.

\section{REFERENCES}

1. Allee W. C., Emerson A. E., Park O., Park T. \& Schmidt K. P., 1958: Zasady ekologii zwierząt. Państw. Wyd, Nauk., 1: 1-600. Warszawa.

2. Baskin L. M., 1970: Severnyj olen, ekologia i povedenije. Nauka: 1-152. Moskva.

3. Bresiński W.: 1975: Přispùsobivost polni srnči zvěře. Myslivost, 1975 (10): $223-224$. 
4. Bresiński W., 1976: „Duże” i „małe" pola miejscem bytowania zwierzyny. Łowiec pol., 7 (1514): 3-4.

5. Bresiński W. \& Chlewski A., 1980: Rola zadrzewień śródpolnych dla zwierzyny we współczesnym krajobrazie rolniczym. Łowiec pol., 3 (1608): 6-7.

6. Büttner K., 1980: Untersuchungen zum Einfluss von Grösse und Zusamensetzung des Wintersprungs beim Rehwild auf die Zeitdauer verschiendener Verhaltenswein. Z. Jagdwiss., 26: 181-194.

7. Dzięgielewski S., 1973: Jeleń. Państw. Wyd. Roln. i Leśne: 1-344. Warszawa.

8. Dzięciołowski R., 1979: Structure and spatial organization of deer populations. Acta theriol., 24: 3-21.

9. Ellenberg H., 1978: Zur Populationsökologiể des Rehes (Capreolus capreolus L., Cervidae) in Mitteleuropa. Zool., Spixiana, suppl. 2: 1-211. München.

10. Estes R. D. \& Estes R. K., 1979: Preliminatory report on the Giant sable (Hippotragus niger variani). Third Progress Report. National Geographic Society. Hippotragine Antelope Study. Msc: 1-22.

11. Franklin W. L., Mossman A. S. \& Dole M., 1975: Social organization and home range of Roosevelt elk. J. Mammal., 56: 102-118.

12. Fruziński B., Łabudzki L. \& Wlazełko M., 1983: Habitat, density and spatial structure of roe deer population in forest. Acta theriol., 28.

13. Graczyk R. \& Bereszyński A., 1978: Obserwacje nad tworzeniem się, organizacją i liczebnością jesienno-zimowych skupień sarn (Capreolus capreolus) w ekosystemie polnym. Roczn. Akad, Roln., Poznań, C, Zootechn., 24: 31-38.

14. Kałuziński J., 1967: Wstępne badania nad rozmieszczeniem przestrzennym sarny polnej. M. Sc. thesis: 1-22. Agric. Acad. Poznań.

15. Kałuziński J., 1982: Dynamics and structure in a field roe deer population. Acta theriol., 27: 385-408.

16. Kitchen D. W., 1974: Social behavior and ecology of the pronghorn. Wildl. Monogr., 38: 1-96.

17. Kummer H. \& Kurt F., 1973: Umwelteinflüsse auf Verhalten einiger Wildtierarten. Wald und Wild, Beiheft Ztschr. schweitz. Forstver., 52: 82-89.

18. Kurt F., 1968: Das Socialverhalten des Rehes (Capreolus capreolus L.). Mammalia depicta: 1-102. Hamburg, Berlin.

19. Leuthold W., 1970: Observations on the social organization of impala (Aecyperos melampus). Z. Tierpsych., 27: 693-721.

20. Leuthold W., 1971: Observations on home range and social organization of Lesser kudu, Tragelaphus imberbis (Blyth, 1869). Tsavo Research Project Kenya National Parks. Preliminary Report: $1-26$. Msc.

21. Manning A., 1976: Wstęp do ekologii zwierząt. Państw. Wyd. Nauk.: 1-404. Warszawa.

22. Meisnerowski St., 1959: Sarna polna w lowiskach Wielkopolski. Łowiec pol., 13 (1112): $4-5$.

23. Metelskij A. P., 1975: Cislennost dikih kopytnyh w Primorskom kraje. Kopytnyje fauny SSSR. Nauka: $55-56$. Moskva.

24. Myrberget S., 1973: Merking av radys i Norge. Fauna, 26: 96-101.

25. Nečas J., 1960: Přispev̌ek k poznáni početnosti, skladby a organisace tlup srnči zvěře (159.2 Capreolus capreolus). Pr. vyzk. Ust. lesn. CSSR, 20: 110-142.

26. Peek J. M., Le Resche R. E. \& Stevens D. S., 1974: Dynamics of moose aggregations in Alaska, Minnesota and Montana. J. Mammal., 55: 126-137.

27. Petrusewicz K., 1965: Dynamika liczebności, organizacja i struktura ekologiczna populacji. Ekol. pol., B, 11: 299-316. 
28. Petrusewicz K., 1978: Osobnik, populacja, gatunek. Państw. Wyd. Nauk.: 1-384. Warszawa.

29. Pielowski Z., 1970: Sarna. Monografia przyrodniczo-łowiecka. Państw. Wyd. Roln. i Leśne: 1-220. Warszawa.

30. Pielowski Z., 1972: Home range and degree of residence of the European hare. Acta theriol., 17: 93-102.

31. Pielowski Z., 1977: das Feldreh - Wild der Zukunft in der Agrar-landschaft. Beiträge zur Jagd- und Wildforschung, 10: 193-200.

32. Pielowski Z., 1983: Some aspects of population structure of field roe deer investigated by visually marking of individuals. Acta theriol., 28.

33. Reichholf J., 1980: Jahreszeit- und Biotopabhängigkeit der Rudelbildung beim Rehwild (Capreolus capreolus L.). Spixiana, 2: 193-208.

34. Schechtel E., 1929: Sarna (szkic lowiecki). Zakłady graficzne „Znicz”: 1-20. Wilno.

35. Sdobnikov W. M., 1935: Vzaimootnošenija sieviernogo olenija s životnym mirom tundry i lesa. Trudy Arkt. Inst., 24: 5-66.

36. Strandgaard H., 1971: Studies on the behaviour of marked roe deer with relation to the regulation of their numbers. Deer, 2: 665-668.

37. Strandgaard H., 1972: The roe deer (Capreolus capreolus) population at Kalø and the factors regulating its size. Danish Rev. Game Biol., 7: 1-205.

38. Tinbergen N., 1951: The study of instinct. Clarendon Press: 1-228. Oxford.

39. Walther F. R., 1970: Age, sex and social status of Thomson's gazelle in correlation with flight from predators (Gazela Thomson). Trudy IX Mezd. Kongr. Bielogov - Ohotovedov: 500-501. Moskva.

40. Zejda J., 1978: Field groupings of roe deer (Capreolus capreolus) in a lowland region. Folia zool., 27: 111-122.

Accepted, May 17, 1982.

Wojciech BRESIŃSKI

\section{GRUPOWANIE SIE SARN POLNYCH \\ W WARUNKACH KRAJOBRAZU ROLNICZEGO}

\section{Streszczenie}

W oparciu o bezpośrednie obserwacje i wizualne znakowanie, w latach 1969-1971 i 1972-1976, na terenie doświadczalnym Stacji Badawczej Polskiego Związku Łowieckiego w Czempiniu badano mechanizmy grupowania się sarn polnych oraz czynniki wpływające na to zjawisko. Stwierdzono, że w okresie letnim (maj- sierpień) zwierzęta te prowadzą samotniczo-rodzinny tryb życia (Fig. 1, 2, 3). Natomiast jesienią i zimą bytują głównie w ugrupowaniach o charakterze mieszanym (Fig. 2) składających się z kilku do kilkudziesięciu osobników. Rozpad zgrupowań następuje na przełomie kwietnia-maja. Srednia wielkość ugrupowań w okresie września-października wynosiła 3,0, listopada-marca 5,6 i kwietnia-maja 3,3 osobnika. Wielkość zgrupowań sarn polnych w głównej mierze zależy od zagęszczenia populacji (Fig. 5). Stwierdzono, także kompleksowy wpływ czynników pogodowych oraz stopnia zadrzewienia terenu (Fig. 7), struktury agrarnej (Fig. 8), 
Skład poszczególnych ugrupowań nie jest stały, ale ulega wahaniom (Tabela 1), między innymi w zależności od lokalnego zagęszczenia populacji (Fig. 9). Wydaje się jednak, że w poszczególnych zgrupowaniach bytują osobniki tworzące niejako jego szkielet, wokb́ł których skupiają się pozostałe osobniki prowadząc niezależny tryb życia. Poszczególne ugrupowania bytują na określonym terenie, którego wielkość waha się w granicach od 69 do około 225 ha (Tabela 2). Ugrupowania sarn polnych wykazują pewien stopień organizacji wewnętrznej, przejawiający się w przewodnictwie i hierarchii socjalnej osobników w zgrupowaniach. Przewodnikami $\mathrm{z}$ reguły są kozy, głównie osobniki w średnim wieku (3-5 lat), które posiadały potomstwo (Tabela 3). Jak się wydaje grupowanie się sarn polnych, jest spowodowane sytuacją stresową jaka powstaje u tych zwierząt, na skutek okresowego braku osłon, wzrostu stopnia penetracji pól przez ludzi oraz oddziaływania czynników pogodowych. Bytując w większych ugrupowaniach, poszczególne osobniki mają większe możliwości pełniejszego zaspokojania swoich potrzeb życiowych. Wydaje się, że grupowanie się sarn polnych w okresie jesienno-zimowym jest przejawem adaptacji do bytowania $w$ warunkach krajobrazu rolniczego oraz wyrazem pogłębiających się różnic ekologicznych pomiędzy sarną bytującą w lesie i na polach. 